\title{
PENDIDIKAN KARAKTER DALAM PEMBELAJARAN BAHASA INDONESIA
}

\author{
Eni Sulistiyowati \\ MTs Masalikil Huda Tahunan Jepara, Jawa Tengah, Indonesia. \\ enisulistiyowati@gmail.com
}

\begin{abstract}
Abstrak
Dewasa ini pemerintah mengalakan pendidikan yang bercirikan dengan agama, atau yang sering disebut dengan pendidikan karakter. Seperti kita ketahui bahwa karakter bangsa Indonesia sekarang merosot. Oleh karena itu pendidikan karakter sebagai solusi untuk untuk membangun karakter bangsa agar memiliki karakter yang baik. Dalam pemberian pendidikan karakter pada sebuah lembaga pendidikan dapat dilakukan dengan menanamkan nilai-nilai pendidikan karakter dalam proses pembelajaran. Penelitian yang menggunakan studi kepustakaan ini bertujuan untuk mengkaji pendidikan karakter yang terdapat dalam pembelajaran bahasa Indonesia. Hasil dari kajian ini menunjukkan bahwap pelaksanaan pendidikan karakter dalam pembelajaran Bahasa Indonesia memerlukan pemahaman guru sebagai pelaksana kurikulum dan fasilitator bagi siswa melalui kegiatan pembelajaran di sekolah sehingga siswa tidak hanya memiliki kompetensi yang baik, melainkan juga memiliki budi pekerti yang terpuji.
\end{abstract}

Kata kunci: pendidikan karakter, pembelajaran Bahasa

Indonesia

\author{
Abstract \\ CHARACTER EDUCATION IN BAHASA INDONESIA \\ LEARNING. Today the government mengalakan education
}


characterized by religion, or what is often referred to as character education. As we know that the character of the Indonesian nation is now in decline. Therefore, character education as a solution to the nation's character in order to build good character. In giving the character education in an educational institution can be done by instilling the values of character education in the learning process. This study whic uses library research, aims to exams the character education contained in Indonesian learning. In this case related to the educational values embodied in learning Indonesian. The result oh this study showed that implementation of character education in learning Indonesian requires understanding the teacher as implementer and facilitator for the student curriculum through learning activities in schools so that students not only have a good competence, but also has a commendable character.

Keywords: character, education, Bahasa Indonesia, learning

\section{A. Pendahuluan}

Pendidikan adalah hal yang penting sepanjang hidup manusia karena pendidikan dapat menghasilkan manusia yang handal dan bermartabat. Pendidikan juga menentukan nasib dan masa depan suatu bangsa. Oleh sebab itu, sistem pendidikan harus selalu menyesuaikan dengan perkembangan zaman. Mengingat peran pendidikan yang sangat strategis, terlebih di era global sekarang ini, sudah seyogyanya segenap potensi bangsa turut serta berupaya meningkatkan kualitas pendidikan. Ilmu pengetahuan dan teknologi berkembang sangat pesat. Dampaknya dapat kita rasakan dalam berbagai aspek kehidupan, tidak terkecuali dalam bidang pendidikan. Perkembangan tersebut di satu sisi berdampak positif, tetapi di sisi lain berdampak negatif. Dampak positif dapat kita rasakan dalam hal kemudahan mendapatkan bernagai informasi melalui kehadiran dunia maya. Begitu dampak negatifnya sekaligus dapat kita rasakan dalam kehidupan sehari-hari antara lain perubahan tata nilai dan norma yang terjadi di masyarakat.

Sebagaimana kita ketahui bersama, sistem pendidikan nasional berfungsi mengembangkan kemampuan dan membentuk watak serta peradaban bangsa yang bermartabat dalam rangka mencerdaskan bangsa. Dalam Kamus Besar Bahasa Indonesia (1990: 389) karakter merupakan sifat-sifat kejiwaan, akhlak atau budi pekerti yang membedakan seseorang dari dari yang lain: tabiat; watak. 
Dengan demikian, karakter (watak; tabiat) dapat dipahami sebagai sikap, tingkah laku dan perbuatan baik atau buruk yang berhubungan dengan norma sosial. Oleh karena itu, erat kaitan antara karakter dan interaksi sosial.

Pendidikan karakter dapat dipengaruhi banyak oleh banyak hal. Diantaranya keluarga, teman, lingkungan, dan bahasa, dan banyak lagi lainnya. Salah satu diantaranya yang paling berpengaruh adalah bahasa. Dalam berkomunikasi bahasa merupakan suatu keharusan dan modal yang mampu menunjukkan identitas diri. Baik dari situasi formal maupun non formal. Bahkan bahasa yang dianggap sebagai budaya berpengaruh besar terhadap pembentukan karakter. Seseorang mulai mengenal bahasa sejak di lingkungan keluarga, kemudian berlanjut ke lingkungan sekolah, dan masyarakat. Ini semua yang disebut lingkungan pendidikan. Namun pendidikan yang ada di lingkungan kita belum mampu memberikan nilai lebih sehingga mampu membuat seseorang menjadi mudah menghadapi masa depannya dengan baik.

Indonesia memerlukan sumber daya manusia dalam jumlah dan mutu yang memadai sebagai pendukung utama dalam pembangunan. Untuk memenuhi sumber daya manusia tersebut, pendidikan memiliki peran yang sangat penting. Hal ini sesuai dengan UU No. 20 Tahun 2003 Tentang Sistem pendidikan nasional pada pasal 3, yang menyebutkan bahwa Pendidikan Nasional berfungsi mengembangkan kemampuan dan membentuk karakter serta peradaban bangsa yang bermartabat dalam rangka mencerdaskan kehidupan bangsa. Pendidikan nasional bertujuan untuk berkembangnya potensi peserta didik agar menjadi manusia yang beriman dan bertaqwa kepada Tuhan Yang Maha Esa, berakhlak mulia, sehat, berilmu, cakap, kreatif, mandiri, dan menjadi warga negara yang demokratis serta bertanggung jawab sedangkan salah satu untuk mendapatkan pendidikan dengan nilai-nilai mulia, berakhlak, kreatif, dan memiliki karakter sesuai budaya bangsa dapat diperoleh melalui penggunaan bahasa yang baik. Seperti yang ditekankan pada pernyataan diatas, bahasa ternyata memiliki peranan dalam pengelolaan dan menciptakan generasi penerus yang memiliki nilai lebih. Dengan alasan itulah, perlunya menganalisa lebih jauh bagaimana pendidikan karakter dalam pembelajaran bahasa. 
Definisi Pendidikan karakter dalam seting sekolah yaitu sebagai pembelajaran yang mrngarah pada penguatan dan pengembangan perilaku anak secara utuh yang didasarkan pada suatu nilai tertentu yang dirujuk oleh sekolah. Definisi ini mengandung makna:

1. Pendidikan karakter merupakan pendidikan yang terintegrasi dengan pembelajaran yang terjadi pada semua mata pelajaran.

2. Diarahkan pada penguatan dan pengembangan perilaku anak secara utuh. Asumsinya anak merupakan oragnisme manusia yang memiliki potensi untuk dikuatkan dan dikembangkan.

3. Penguatan dan pengembangan perilaku didasari oleh nilai yang dirujuk oleh sekolah (lembaga).

Sebagai makhluk sosial manusia tentu melibatkan bahasa saat berinteraksi dengan sesamanya. Bahasa merupakan unsur penting kebudayaan. Transformasi budaya selama ini berlangsung tiada lain karena peran bahasa pula. Ungkapan "Bahasa menunjukkan bangsa" telah terbukti. Melalui bahasa kita dapat mengetahui budaya dan pola pikir suatu masyarakat. Menurut Keraf (1997: 1) Bahasa adalah alat komunikasi antara anggota masyarakat berupa simbol bunyi yang dihasilkan oleh alat ucap manusia. Bahasa haruslah merupakan bunyi yang dihasilkan oleh alat ucap manusia. Bukannya sembarang bunyi. Dan bunyi itu sendiri haruslah merupakan simbol atau lambang.

Menurut para ahli, Plato mengemukakan bahwa bahasa pada dasarnya adalah pernyataan pikiran seseorang dengan perantaraan onomata (nama benda atau sesuatu) dan rhemata (ucapan) yang merupakan cermin dari ide seseorang dalam arus udara lewat mulut. Carrol berpendapat bahwa bahasa adalah sebuah sistem berstruktural mengenai bunyi dan urutan bunyi bahasa yang sifatnya manasuka, yang digunakan, atau yang dapat digunakan dalam komunikasi antar individu oleh sekelompok manusia dan yang secara agak tuntas memberi nama kepada benda-benda, peristiwa-peristiwa dan prosesproses dalam lingkungan hidup manusia. Sudaryono mengemukakan bahwa bahasa adalah sarana komunikasi yang efektif walaupun tidak sempurna sehingga ketidaksempurnaan bahasa sebagai sarana komunikasi menjadi salah satu sumber terjadinya kesalahpahaman.

Dapat disimpulkan bahwa bahasa alat komunikasi antara anggota masyarakat berupa simbol bunyi yang dihasilkan oleh alat 
ucap manusia. Bahasa memberikan kemungkinan yang jauh lebih luas dan kompleks daripada yang dapat diperoleh dengan mempergunakan media. Bahasa haruslah merupakan bunyi yang dihasilkan oleh alat ucap manusia. Bukan sembarang bunyi karena bunyi itu sendiri haruslah merupakan simbol atau perlambangan.

Bahasa adalah budaya Inilah yang menjadi sorotan masyarakat, bahasa merupakan ciri dari budaya suatu daerah atau personal yang ada dalam diri seseorang. Bagaimana jika budaya salah satu masyarakat menjadi suatu hal yang sulit diterima masyarakat, bisa jadi karena salah satu faktor yaitu bahasa yang kurang tepat, dan itu bisa saja terjadi pada anak didik kita jika tidak ditanamkan sejak dari awal pentingnya ketepatan bahasa maka akan besar pengaruhnya terhadap budaya mereka dan pendidikannya ke depan. Penanaman nilai dalam suatu pendidikan harus diterapkannya, pentingnya pendidikan karakter yang memasukkan unsur penting seperti budi pekerti, pengetahuan, tindakan, dan kesemua itu dilakukan dengan tingkat kesadaran yang tinggi. Penanaman sejak dini memberikan dampak besar bagi anak ke depannya. Bahasa Indonesia sangatlah penting untuk dipelajari karena Bahasa Indonesia merupakan bahasa nasional yang menjadi identitas dari bangsa Indonesia. Pentingnya pendidikan karakter dan pembelajaran Bahasa Indonesia akan diintegrasikan dalam proses belajar mengajar.

Istilah pembelajaran sering terdengar dalam kajian pendidikan di sekolah saat ini. Istilah ini merupakan pengembangan istilah dari "Proses Belajar Mengajar" (PBM). Dalam istilah PBM makna yang familiar bagi guru-guru saat ini adalah guru melakukan pengajaran dalam berbagai materi ajar kepada peserta didik. Sedangkan istilah pembelajaran saat ini menjadi aktual, dimaknai sebagai proses interaksi peserta didik dengan lingkungan belajarnya. Dalam proses ini anak menjadi objek sekaligus subjek belajar. Guru dan lingkungan belajar lainnya menjadi kondisi penting yang menyertai proses pembelajaran.

Pembelajaran dalam pendidikan karakter didefinisikan sebagai pembelajaran yang mengarah pada penguatan dan pengembangan perilaku anak secara utuh yang didasarkan atau dirujuk pada suatu nilai. Penguatan adalah upaya untuk melapisi suatu perilaku anak sehingga kuat. Pengembangan perilaku adalah proses adaptasi perilaku 
anak terhadap situasi dan kondisi baru yang dihadapi berdasarkan pengalaman baru. Kegiatan penguatan dan pengembangan didasarkan pada suatu nilai yang dirujuk. Artinya proses pendidikan karakter adalah proses yang terjadi karena didesain secara sadar, bukan suatu kebetulan.

Menurut Woolfork pembelajaran berlaku apabila sesuatu pengalaman secara relatifnya menghasilkan perubahan kekal dalam pengetahuan dan tingkah laku. Pembelajaran menurut Knowles adalah cara pengorganisasian peserta didik untuk mencapai tujuan pendidikan. Pendidikan karakter secara terintergrasi di dalam proses pembelajaran adalah pengenalan nilai-nilai, fasilitasi diperolehnya kesadaran akan pentingnya nilai-nilai, dan penginternalisasian nilainilai kedalam tingkah laku peserta didik sehari-sehari melalui proses pembelajaran baik yang berlangsung di dalam maupan di luar kelas pada semua mata pelajaran, selain untuk menjadikan peserta didik menguasai materi yang ditargetkan, juga dirancang dan dilakukan untuk menjadikan peserta didik mengenal, menyadari/peduli, dan menginternalisasi nilai-nilai dan menjadikannnya perilaku.

\section{B. Pembahasan}

\section{Hubungan Pendidikan Karakter dengan Pembelajaran bahasa Indonesia}

Pendidikan karakter mulai didengungkan di era Mendikbud Muhammad Nuh. Menurutnya pendidikan di Indonesia mulai melupakan pembentukan karakter siswa. Atas dasar pemikiran itulah pendidikan saat ini harus memuat pendidikan karakter. Koesuma dalam artikelnya menyatakan tujuan pendidikan adalah untuk pembentukan karakter yang terwujud sdalam kesatuan esensial si subjek dengan perilakun dan sikap hidup yang dimilikinya. Karakter menjadi identitas yang mengatasi pengalaman kontingen yang selalu berubah. Dari kematangan karakter inilah, kualitas seseorang secara pribadi mampu diukur.

Bahasa mencerminkan bangsa. Itulah kira-kira gambaran bagaimana hubungan bahasa dengan pendidikan karakter. Bahasa yang notabene alat komunikasi mempunyai dampak yang besar terhadap perilaku manusia. Hal tersebutlah yang meyakini setiap tuturan yang diucapkan manusia mempunyai karakter tersendiri. 
Karakter yang diungkapkan dalam hal ini merujuk pada pedoman Kementrian Pendidikan Nasional mengenai delapan belas karakter yang menjadi petunjuk pendidikan karakter, diantaranya religius, jujur, disiplin, kerja keras, semangat kebangsaan, cinta tanah air, peduli lingkungan, peduli sosial, tanggung jawab, rasa igin tahu, gemar membaca, kreatif, mandiri, demokratis, cinta damai, menghargai prestasi, tileransi dan komunikatif

Hubungan pendidikan karakter dengan pembelajaran Bahasa Indonesia itu sama penting. Hal ini dikarenakan antara keduanya memiliki keterkaitan satu sama lain. Di sisi lain Bahasa Indonesia memiliki perana yang sangat penting yaitu bahasa memiliki fungsi sebagai lat komunikasi dalam berbagai kontek. Baik komunikasi secara tulis maupun lisan. Hal ini dapat dilihat dari pemakaian bahasa di dalam masyrakat akademik yang dapat difungsikan pada penulisan karya ilmiah seperti ringkasan buku, makalah seminar, lokakarya, skripsi, tesis, dan disertasi. Semua karya tersebut sebagai wujud komunikasi tulis dalam dunia akademik. Demikian pula komunikasi lisan dapat dilihat wujudnya pada waktu civitas akademik memeberikan materi di kelas, seminar, orasi ilmiah, dan pidato pengukuhan doctor maupun guru besar.

Tuturan-tuturan yang dikemukakan diatas memiliki konteks kalimat yang beragam. Masing-masing memegang peran dalam interaksi antara penutur, lawan tutur, dan partisipasinya. Oleh karena itu, makna kalimat baik tersurat maupun tersirat masing-masing dapat dimaknai berdasarkan siapa, apa, dimana, kapan, mengapa, dan bagaimana tuturan itu diucapkan dalam sebuah percakapan atau wacana. Menurut Kartomihardjo (1993: 26-28) bahwa konteks tuturan dapat dipilih menjadi:

1. Konteks yang berhubungan dengan pembicara dan pendengarnya.

2. Konteks yang berhubungan dengan tempat dan waktu.

3. Konteks yang berhubungan dengan topik pembicaraan.

4. Konteks yang berhubungan dengan saluran yang digunakan, misalnya tulisan, lisan, isyarat, kentongan dan sebagainya.

5. Konteks yang berhubungan dengan kode yang digunakan dalam komunikasi

6. Konteks yang berhubungan dengan bentuk pesan dan isinya. 
Konteks yang berhubungan dengan bentuk pesan dan isinya.

7. Konteks yang berhubungan dengan peristiwa dan sifatsifatnya yang khusus.

8. Konteks yang berhubungan dengan nada pembicaraan, serius, sinis, sarkastik, rayuan, dan lain-lain.

Konteks-konteks diatas, jika dikaitkan antara pembelajaran Bahasa Indonesia dengan pendidikan karakter tentunya memiliki hubungan. Dalam proses pembelajaran Bahasa Indonesia sendiri tentunya digunakan beberapa konteks diatas. Baik itu ketika proses pembelajaran berlangsung maupun diluar proses pembelajaran. Penggunaan beberapa konteks dalam sebuah tuturan berkenaan dengan komunukasi dapat diketahui bagaimana karakter atau kepribadian seseorang. Kebribadian terasebut dapat dilihat dari bagaimana tutur kata seseorang dalam berkomunikasi, gaya bahasa yang digunakan dan keefektifan kata demi kata pada saat berkomunikasi dengan orang lain sehingga mudah untuk dipahami. Apabila bahasa yang digunakan seseorang pada saat berkomunikasi baik, teratur, dan mudah dipahami maka orang lain kan beranggapan bahwa orang tersebut memiliki kepribadian yang baik. Begitu pula sebaliknya, jika penggunaan bahasa yang digunakan seseorang padsa saat berkomunikasi tidak teratur, dan sulit dipahami, maka orang lain akan beranggapan bahwa orang tersebut memiliki kepribadian yang kurang baik.

Terkadang tidak jarang dari gaya bahasa, bagaiman cara penyampaiannnya, ekspresinya, dan keefektifan bahasa yang digunakan dalam berkomunikasi dapat diketahui tingkat kejujuran atau kebenaran ucapan seseorang. Biasanya orang yang jujur selalu menggunakan bahasa yang teratur dan menggunakan kalimat yang efektif pada saaat berbicara tidak bertele-tele, ekspresinya tenang tidak kelihatan takut dan ragu-ragu, serta kata-kata yang diucapkan dapat diyakini kebenarannya.

Penggunaan tutur bahasa seseorang dalam berkomunikasai dapat diketahui tingkat intelektualitas seseorang. Jika seorang yang memiliki daya intelektual yang tinggi maka bahas yang digunakan teratur, mudah dipahami, kata-kata yang diucapkan dapat meyakinkan pendengarnya, terlihat tenang pada saat berbicaram dan kata- kata 
yang digunakannya pun sopan dan santun. Kesopanan seseorang juga dapat dilihat dari bahasa yang digunakannya dalam berkomunikasi dengan orang lain.

Bahasa Indonesia yang digunakan oleh kelompok penutur yang berpendidikan tampak jelas perbedaannya dengan Bahasa Indonesia yang digunakan oleh kelompok penutur yang tidak berpendidikan, terutama dalam pelafalan kata yang berasal dari bahasa asing, pitamin, pilem, komplek. Perbedaan ragam bahasa penutur yang berpendididkan dan tidak berpendidikan juga tampak dalam bidang tata bahasanya. Misalnya: mbawa (membawa), nyari (mencari), atau dalam susunan kalimat, misalnya: Ini hari Aminah akan ke Solo. Demikian juga pemakaian kalimat. Misalnya pemakaian kalimat Saya akan ceritakan tentang Kancil dan Buaya. Hal ini memperlihatkan penuturnya kurang dapat memelihara bahasanya. Ragam bahasa yang dituturkan oleh kelompok penutur berpendidikan memiliki ciri keterpeliharaan. Ragam bahasa itu digunakan dalam dunia pendidikan, lembaga pemerintahan, media massa, ilmu dan teknologi. Ragam itu memiliki prestis yang tinggi.

Berkaitan dengan proses pembelajaran seorang guru dapat mengetahui karakter atau kepribadian peserta didiknya melalui bahasa yang digunakan pada saat berkomunikasi baik di dalam maupun di luar proses pembelajaran. Seseorang guru dapat mengetahui kejujuran, daya intelektual, kesopanan dan karakter dari peserta didiknya dapat diketahui dari tutur bahasa, ekspresi, kalimat yang efektif, dan cara penyampaian yang digunakan pada saat berkomunikasi, baik dengan gurunya, teman-temannya, maupun orang lain. Bahasa yang dimaksudkan dalam berkomunikasi disini bisa lisan maupun tulisan.

Pendidikan karakter dengan proses pembelajaran Bahasa Indonesia memiliki hubungan satu dengan yang lain. Pendidikan karakter terkandung dalam proses pembelajaran bahasa Indonesia. Dalam pembelajaran Bahasa Indonesia terdapat nilai-nilai pendidikan karakter diantaranya kejujuran, intelektualitas, sopan santun, dan rasional. Pendidikan berbasis karakter merupakan salah satu upaya dalam pembaharuan di dunia pendidikan, besar pengaruhnya penanaman karakter pada anak dianggap sebagai hal pokok. Hal ini mengisyaratkan bahwa mutu pendidikan peserta dididk sangat penting untuk ditingkatkan. 
Karakter merupakan nilai-nilai perilaku manusia yang berhubungan dengan Tuhan Yang Maha Esa, diri sendiri, sesama manusia, lingkungan, dan kebangsaaan yang terwujud dalam pikiran, sikap, perasaan, perkataan, dan perbuatan berdasarkan norma-norma agama, hukum, tata krama, budaya, dan adat istiadat. Menurut Foerster ada empat ciri dasar dalam pendidikan karakter, yaitu:

1. Keteraturan interior dimana setiap tindakan diukur berdasar hierarki nilai. Nilai menjadi pedoman normatif setiap tindakan.

2. Koherensi yang member keberanian, membuat seseorang teguh pada prinsip, tidak mudah terombang ambing pada situasi baru atau takut risiko. Koherensi merupakan dasar yang membangun rasa percaya satu sama lain. Tidak hanya koherensi meruntuhkan kredibilitas seseorang.

3. Otonomi, dimana seseorang mengintenalisasikan aturan dari luar sampai menjadi nilai-nilai bagi pribadi.Ini dapat dilihat lewat penilaian atas keputusan pribadi tanpa terpengaruh atau desakan pihak lain.

4. Keteguhan dan kesetiaan. Keteguhan merupakan daya tahan seseorang guna menginginkan apa yang dipandang baik. Kesetiaan merupakan dasar bagi penghormatan atas komitmen yang dipilih.

Kematangan keempat karakter ini memungkinkan manusia melewati tahap individualitas menuju personalitas. "Orang-orang modern sering mencampuradukkan antara individualitas dan personalitas, antara aku alami dan aku rohani, antara independensi eksterior dan interior". Karakter inilah yang menentukan format seorang pribadi dalam segala tindakannya. Pendapat Foester ini semakin mendukung program pendidikan yang tidak hanya berfungsi sebagai lembaga yang memberdayakan anak dalam pengertian kecerdasan dan keterampilan melainkan program pendidikan juga menyadarkan tentang pentingnya menjaga moralitas dan peningkatkan kemampuan pertimbangan rasional dalam pengambilan keputusan. Apabila segala fenomena tentang pentingnya pendidikan tidak terealisasi dengan baik, maka keberhasilan pemerhati pendididkan karakter akan mengalami kegagalan. Dampak yang dinilai sangat mempengaruhi pendidikan anak adalah lingkungan, baik keluarga, sekolah maupun 
masyarakat. Pemberian pendidikan akan tersampaikan dengan baik jika penggunaan bahasa diberikan dengan tepat.

Bahasa yang sopan, baik dan tidak mampu membuat anak merasa tertekan. Bahasa dapat pula berperan sebagai alat integrasi sosial sekaligus alat adaptasi sosial, hal ini mengingatkan bahwa bangsa Indonesia memiliki bahasa yang majemuk. Kemajemukan itu membutuhkan satu alat sebagai pemersatu keberseragaman tersebut. Disinilah fungsi bahasa sangat diperlukan alat integrasi sosial. Bahasa disebut sebagai alat adaptasi apabila seseorang berada di suatu tempat yang memiliki perbedaan adat, tata karma dan aturan-aturan dari tempatnya berasal. Proses adaptasi ini akan berjalan baik apabila terdapat sebuah alat yang membuat satu sama lainnya mengerti, alat tersebut disebut bahasa. Hal ini menunjukkan bahwa bahasa merupakan sesuatu yang sangat penting bagi manusia.

Salah satu butir sumpah pemuda adalah menjunjung tinggi bahasa persatuan, Bahasa Indonesia. Dengan demikian bahasa dapat mengikat anggota-anggota masyarakat pemakai bahasa menjadi masyarakat yang kuat, bersatu, dan maju. Pengaruh penting terhadap pendidikan karakter yaitu bahasa. Bahasa adalah seperangkat kebiasaan, kebiasaaan bisa dikatakan adat. Dalam situs Wikipedia menyebutkan bahwa adat ialah gagasan kebudayaan yang terdiri dari nilai-nilai kebudayaan, norma, kebiasaan, kelembagaan, dan hukum adat yang lazim dilakukan di suatu daerah. Apabila adat ini tidak dilaksanakan akan terjadi kerancuan yang menimbulkan sanksi tak tertulis oleh masyarakat setempat terhadap pelaku yang dianggap menyimpang.

Stevick dalam Sudana menyatakan maksud dari pengajaran bahasa adalah meningkatkan harga diri, menumbuhkan pikiran positif, meningkatkan pemahaman diri, menumbuhkan keakraban dengan orang lain, dan mampu menemukan kelebihan dan kelemahan diri. Dari pernyataan tersebut maksud pengajaran bahasa berorientasi pada pemerolehan nilai-nilai sesuai pendidikan karakter yaitu menumbuhkan pikiran positif dan menumbuhkan keakraban dengan orang lain. 


\section{Nilai-nilai Pendidikan Karakter dalam Pembelajaran Bahasa Indonesia}

Dalam penguasaan Bahasa Indonesia ada dua yaitu:

1. Penguasaan bahasa yang pasif meliputi:

a. Mendengarkan

Mendengarkan adalah mengarahkan perhatian dengan sengaja kepada suatu suara atau menangkap pikiran orang yang berbicara dengan alat pendengaran kita, dengan tepat dan teratur. Dengan membiasakan mendengarkan keterangan dari orang lain, maka akan terbentuk karakter setia, sehingga ia menghargai pendapat orang lain.

b. Membaca

Membaca adalah menangkap pikiran dan perasaan orang lain dengan perantara tulisan. Membaca pada hakikatnya adalah suatu yang rumit yang melibatkan banyak hal, tidak hanya sekedar melafalkan tulisan, tetapi juga melibatkan aktivitas visual, berfikir, psikolinguistik, dan metakognitif. Sebagai proses visual, membaca merupakan proses menerjemahkan simbol tulis ke dalam kata-kata lisan.

Tujuan membaca yaitu menangkap bahasa yang tertulis dengan tepat dan teratur, lebih rincinya, tujuan membaca sebagai berikut:

1. Untuk mengerti atau memahami isi atau pesan yang terkandung dalam satu bacaan seefisien mungkin.

2. Morrow (1981: 89-104) mengatakan bahwa tujuan membaca ialah untuk mencari informasi :

a. Kognitif dan intelektual yakni yang digunakan seseorang untuk menambah keilmihannya sendiri.

b. Referensial dan factual yakni yang digunakan seseorang untuk mengetahui fakta-fakta yang nyata di dunia ini.

c. Afektif dan emosional, yakni yang digunakan seseorang untuk mencari kenikmatan dalam membaca.

Adapun manfaat dan faedah membaca adalah:

1. Membaca mengambil tempat sebagai pembantu bagi seluruh 
mata pelajaran khususnya Bahasa Indonesia.

2. Mempunyai nilai praktis. Membaca merupakan alat menambah pengetahuan.

3. Sebagai penghibur. Untuk mengisi waktu luang (seperti: membaca syair, sajak, roman, majalah, novel, dan sebagainya).

4. Memperbaiki akhlak dan bernilai keagamaan yaitu dengan membaca buku-buku yang bernilai etika atau keagamaan.

5. Bernilai fungsional. Membaca berguna bagi pembentukan fungsi-fungsi kejiwaan seperti: daya ingatan, daya fantasi, daya fikir. Berbagai jenis perasaan dan sebagainya.

Nilai-nilai pendidikan karakter yang terkandung dalam membaca pada pembelajaran Bahasa Indonesia diantaranya adalah bisa menghargai karya orang lain, kreatif, tanggung jawab, rasa ingin tahu terhadap hal-hal yang positif dan lain sebagainya.

Peran bahasa dalam membangun karakter bangsa tidak akan optimal jika kemampuan berbahasa Indonesia masih rendah. Dalam Ujian Nasional berdasarkan data dari Mendikbud mayoritas kegagalan siswa SMA dalam Ujian nasional adalah pada pelajaran Bahasa Indonesia dan Matematika. Satria Darma, ketua Ikatan Guru Indonesia menyatakan rendahnya nilai Bahasa Indonesia dalam UN diebabkan oleh rendahnya keterampilan membaca. Budaya literasi di Indonesia belum dianggap sebagi suatu hal yang penting. Minat baca bangsa sangat mengkhawatirkan, padahal dari membaca kemampuan berbahasa lainnya seperti menulis dan berbicara akan meningkat. Membaca adalah jendela dunia yang membuat manusia dekat dengan karya sastra, buku, karakter bangsa, dan peradaban.

Penguasaan bahasa aktif terdiri dari:

a. Bercakap-cakap

Bercakap-cakap maksudnya melahirkan pikiran dan perasaan yang teratur, dengan menggunakan bahasa lisan. Berkenaan dengan bercakap-cakap sering juga dikaitkan dengan bercerita. Kedua pengertian itu memang berbeda, dan digunakan untuk pengajaran yang berbeda maksud serta pelaksanaannya.

Di dalam pembelajaran pengajaran bercakap-cakap peserta didik yang aktif melakukannya. Tujuannya adalah melatih anak 
supaya dapat melahirkan perasaan dan pikirannnya dengan teratur secara lisan. Sedangkan guru, dalam hal ini hanyalah memimpin dan memberi petunjuk-petunjuk seperlunya.

Bercerita merupakan bentuk mengajar yang dapat digunakan terhadap berbagai matapelajaran. Dalam pengajaran bercerita guru yang aktif bercerita, para siswa mendengarkan. Tujuan pengajaran bercerita tergantung kepada isi dan cara melaksanakan/menyajikan bahan.

Bercakap-cakap dapat dibagi menjadi dua macam yaitu bercakap-cakap spontan dan bercakap-cakap terpimpin. Adapun tujuan bercakap-cakap spontan adalah:

1. Melatih siswa melahirkan isi hatinya (pikiran, perasaan, dan kemauannnya) secara lisan dengan bahasa yang teratur dan kalimat yang baik.

2. Memperbesar dorongan batin akan melahirkan isi hatinya.

3. Memupuk keberanian bercakap-cakap pada siswa.

4. Menambah perbendaharan bahasa anak.

5. Dari sudut psikologi humanisnya adalah memberikan kesempatan pada siswa untuk menyatakan dirinya.

Tujuan dari bercakap-cakap terpimpin adalah untuk membuat siswa berani menyatakan pendapatnya, menghilangkan rasa malu dan ragu-ragu. Nilai-nilai pendidikan karakter yang terdapat dalam materi bercakap-cakap diantaranya adalah keberanian, kejujuran, rasional, tanggung jawab, menghargai pendapat orang lain dan sebagainya.

b. Mengarang atau menulis

Mengarang adalah melahirkan pikiran dan perasaan dengan cara yang teratur, dan dituliskan dalam bahasa tulisan. Jika mengarang dikaitkan dengan bercakap-cakap, keduanya memiliki persamaan dan perbedaan. Persamaannya adalah keduanya merupakan bentuk bahasa yang aktif dalam menyatakan pikiran dan perasaan. Sedangkan perbedaannnya adalah sebagai berikut:

1. Di dalam bercakap-cakap, selain bunyi/suara, masih banyak lagi alat-alat pernyataan yang ada pada diri seseorang yang turut memperjelas pernyataan seseorang tersebut, seperti tekanan kata/kalimat, bercakap-cakap dengan bernafsu, bersemangat, dengan cepat atau lambat, dengan tenang atau 
gugup dapat didengar dari nada bercakapnya. Sedangkan dalam mengarang kita hanya dapat menyatakan seperti itu dengan menggaris bawahi atau memberi warna pada kata-kata atau bagian-bagian kalimat atau dengan memberi berbagai macam tanda baca.

2. Dalam bercakap-cakap gerak gerik muka dapat digunakan. Sedangkan pada menulis/ mengarang hanya dengan sebuah gambar atau menyebutkan gerak-gerik.

3. Dalam bahasa tulisan haruslah lebih jelas dan lebih seksama di dalam mengungkapkan pernyataannya, harus memperhatikan kata yang tepat untuk kalimat dan susunan yang benar dari pelahiran kata seluruhnya, dengan kata lain dalam mengarang kalimat benar-benar berisi atau efektif.

Tujuan dari mengarang sebagi berikut:

1. Memperkaya perbendaharaan bahasa pasif dan aktif.

2. Melatih melahirkan pikiran dan perasaan dengan lebih teratur secara tertulis.

3. Latihan memaparkan pengalaman-pengalaman yang tepat.

4. Latihan-latihan penggunaan ejaan yang tepat.

Dalam menulis atau mengarang memiliki beberapa macam. Untuk pembelajaran Bahasa Indonesia di SMP/Tsanawiyah berkenaan dengan materi menulis atau mengarang, sering dikenal dengan menulis karya tulis ilmiah dan non ilmiah. Dalam menulis karya tulis ilmiah harus diketahui terlebih dahulu ciri-ciri dari karya tulis ilmiah tersebut, diantaranya:

1. Reproduktif, informasi yang disampaikan penulis diterima oleh pembaca.

2. Tidak ambigu, artinya tidak bermakna ganda akibat penulisnya kurang menguasai materi atau kurang mampu menyusun kalimat dengan subjek dan predikat yang jelas.

3. Tidak emotif, artinya tidak melibatkan aspek perasaan penulis.

4. Penggunaan bahasa baku dalam ejaan, kata, kalimat dan paragraf.

5. Penggunaan istilah keilmuan di bidang tertentu sebagi bukti. 
6. Bersifat denotatif artinya karya tulis harus menggunakan istilah atau kata yang hanya memiliki satu makna.

7. Rasional artinya keruntutan pikiran yang logis, alur pemikiran yang lancar dan kecermatan tulisan.

8. Ada kohesi antarkalimat pada setiap paragraph dan koherensi antarpargraf dalam setiap bab.

9. Bersifat langsung ke sasaran.

10. Penggunan kalimat efektif artinya kalimat itu padat berisi, tidak berkepanjangan sehingga makna yang hendak disampaikan kepada tepat mencapai sasaran.

11. Syarat-Syarat karya tulis ilmiah yaitu:

12. Komunikatif artinya uraian yang disampaikan mudah dipahami pembaca.

13. Bernalar artinya tulisan harus sistematis, berurutan logis, ada kohesi dan koherensi, mengikutu metode ilmiah, dipdpdrkan secara objektif benar dan dapat dipertanggungjawabkan.

14. Ekonomis artinya kata atau kalimat yang ditulis hendaknya diseleksi.

15. Memiliki landasan teori.

16. Bertanggung jawab artinya sumber data harus disebutkan.

Dari ciri-ciri dan syarat-syarat dalam penulisan karya tulis ilmiah diatas dapat dikaitkan dengan pendidikan karakter. Dalam proses pembelajaran Bahasa Indonesia berkaitan dengan penulisan karya tulis ilmiah itu sendiri terdapat beberapa nilai-nilai pendidikan karakter yang dapat diimplementasikan, diantaranya sebagai berikut:

1. Keberanian

Peserta didik dapat memiliki keberanian sendiri untuk mengemukakan pendapat-pendapatnya, sehingga akan memiliki pengalaman tersendiri dari hasil karya tulis yang disusunnya, baik itu ringkasan buku, makalah, artikel dan sebagainya.

2. Kejujuran

Dengan adanya tugas membuat sebuah karya tulis ilmiah seorang guru bisa mengetahui kebenran data atau cerita yang dituliskan oleh para peserta didiknya. Dengan demikian dapat diketahui hasil karya yang dihasilkan sendiri. 
3. Bertanggung jawab

Peserta didik dapat diajarkan untuk bertanggung jawab terhadap hasil karya yang telah dihasilkan apapun bentuknya baik itu makalah, artikel, esai, ringkasan buku dan sebagainya.

4. Kreatif

Peserta didik dapat menigkatkan kreatifitasnya untuk menulis, baik karya tulis ikmiah maupun non ilmiah, sehingga hal ini menjadi jembatan untuk menjadi seorang penulis.

5. Rasional

Dengan melatih peserta didik untuk menulis karya tulis ilmiah, itu berarti seorang guru telah mengajarkan kepada peserta didik untuk berfikir rasional atau masuk akal sehungga akan tertanam sifat rasional pada jiwanya.

6. Tidak egois

Peserta didik akan belajar untuk tidak egois dalam mengemukakan pendapatnya pada karya tulis. Dalam penulisan karya tulis ilmiah tidak dibenarkan penulis menulis dat atau keterangan berdasarkan perasaan atau emosional penulis. Oleh karena itu data atau keterangan yang ditulis penulis harus objektif.

Rendahnya kemampuan berbahasa harus dapat diatasi agar proses membangun karakter bangsa melalui bahasa dapat tercapai.

\section{Simpulan}

Bahasa sebagai wahana pendidikan karakter perlu direncanakan, dibina, dan dimodemkan. Strategi yang yang efisien dan efektif untuk untuk mewujudkannnya tiada lain adalah melalui pendidikan dan pembelajaran. Oleh karena itu, perencanaan pengajaran bahasa yang terpadu dan sinergis perlu diupayakan. Bahasa merupakan suatu hal yang dianggap perlu untuk dilaksanakan pada lingkungan pendidikan, karena pemerolehan bahasa dikaitkan dengan penguasaan sesuatu bahasa tanpa disadari atau dipelajari secara langsung yaitu tanpa melalui pendidikan secara formal untuk mempelajarinya. Sebaliknya memeperolehnya dari bahasa yang dituturkan oleh ahli masyarakat di sekitarnya. Bahasa diberikan pada 
lingkungan pendidikan, dan dimulai dari usia anak-anak, sehungga penanaman nilai-nilai yang diberikan sejak anak-anak dinilai lebih maksimal daripada diberikan pada usia dewasa.Pendidikan karakter dalam pembelajaran Bahasa Indonesia adalah pengenalan nilai-nilai, fasilitasi diperolehnya kesadaran akan pentingnya nilai-nilai, dan penginternalisasian nilai-nilai ke dalm tingkah laku peserta didik sehari-hari melalui proses pembelajaran baik yang berlangsung didalam maupun diluar kelas pada mata pelajaran bahasa Indonesia.

Berkenaan dengan materi yang mengandung nilai-nilai pendidikan karakter dalam pembelajaran bahasa Indonesia adalah mendengarkan, membaca, bercakap-cakap, mengarang dan menulis, Secara umum nilai-nilai yang terdapat pada materi-materi pembelajaran bahasa Indonesia adalah kejujuran, keberanian, rasional, kreatifitas, menghargai, kerja keras, sopan santun dan sebagainya. Terselenggaranya pendidikan di tiga lingkungan sangat memungkinkan penggunaan bahasa memiliki pengaruh yang besar, Dari cerminan tersebut perlunya pengajaran bahasa dan kaitannya dengan pendidikan dinilai mampu memberikan hal positif dalam pembentukan karakter seseorang melalui pendidikan berbasis karakter. Mempelajari dan mengembangkan bahasa dalam pendidikan sangatlah perlu ditingkatkan. Oleh sebab itu kita sebagai pemerhati pendidikaan mempunyai peran penting dalam menanamkan nilainilai positif serta pembentukan karakter seseorang melalui bahasa yang baik.

Melalui data kebahasaan, kita dapat mengetahui karakter bangsa ini. Secara umum masyarakat kita sangat mementingkan kasih sayang terhadap sesamanya. Sebagai pengejawantahan karakter bangsa melalui sikap positif berbahasa dalam mengekspresikan kekinian kita perlu mempertimbangkan kembali penggunaan kata-kata asing di tempat umum. Bahasa mencerminkan bangsa, setiap tuturan yang diucapkan manusia mempunyai karakter tersendiri. Dan sebaliknya ada yang peka terhadap hal ini. 


\section{DAFTAR PUSTAKA}

Departemen Pendidikan dan Kebudayaan. 1990. Kamus Besar Bahasa Indonesia. Jakarta: Balai Pustaka.

Depdiknas.2003. UU No. 20 tahun 200, Sistem Pendidikan Nasional. www.depdiknas.go.id.

Keraf, Gorys. 1997. Komposisi: Sebuah Pengantar Kemahiran Bahasa. Ende-Flores: Nusa Indah.

Kartomihardjo, Soeseno. 1993. Analisis Wacana dengan Penerapannya pada Beberapa Wacana. Jakarta: Lembaga Bahasa Unika Atmajaya.

Dharma, Kesuma dkk.2011. Pendidikan Karakter Kajian Teori dan Praktek di Sekolah. Bandung: PT Remaja Rosdakarya.

Nababan, Sri Subakto. 1992. Metodologi Pengajaran Bahasa. Jakarta: PT Gramedia.

Purwanto, M Ngalim. 1997. Metodologi Pengajaran Bahasa Indonesia di Sekolah Dasar. Jakarta: PT Rosda Jayaputra.

Rohmadi, Ahmad dan Anindiyta Sri Nugraheni. 2011. Belajar Bahasa Indonesia: Upaya Terampil berbicara dan Menulis Karya Ilmiah. Surakarta: Cakrawala media.

Rohmadi, Muhammad dkk. 2008. Teori dan aplikasi: Bahasa Indonesia di Perguruan Tinggi. Surakarta: UNS Press.

Sudrajat, Akhmad. 2010. Mengaktifkan Siswa dalam Belajar. Diakses dari http://akhmadsudrajat.wordpress.com/2014/11/20/

Sudrajat, Akhmad. 2010. Peran Pendidikan Menuju Bangsa yang Bermartabat. Diakses dari http://akhmadsudrajat.wordpress. com/2014/11/20/

Sugono, Dendy. 1986. Berbahasa Indonesia dengan Benar. Jakarta: PT Priastu.

Tim Penyusun Kamus. 1990. Kamus Besar Bahasa Indonesia. Jakarta: Balai Pustaka. 
Eni Sulistiyowati

halaman ini bukan sengaja dikosongkan 